\title{
Karakteristik Sebaran Fitoplankton di Perairan Muara Sungai Sugihan, Sumatera Selatan
}

\author{
Mulyadi1, Tengku Zia Ulqodry1,2*, Riris Aryawati 1,2, Isnaini1,2 dan Heron Surbakti1,2 \\ IProgram Studi Ilmu Kelautan, Fakultas Matematika dan Ilmu Pengetahuan Alam, Universitas \\ Sriwijaya \\ 2Pusat Penelitian Perikanan dan Kelautan, Universitas Sriwijaya \\ Jl. Srijaya Negara Bukit Besar, Palembang, Sumatera Selatan Indonesia 30128
}

Email: zia_uul@unsri.ac.id

\begin{abstract}
The Characteristic of Phytoplankton Distribution at Sugihan Estuary, South Sumatera
\end{abstract}

The anthropogenic activity around Sugihan Estuary might drive changes on physicalchemical factors which affect the abundance and distribution of phytoplankton in the Sugihan Estuary. The purpose of this study was to analyze the abundance and distribution of phytoplankton based on physical-chemical parameters at Sugihan Estuary, South Sumatera. Samples were taken at 18 stations in towards low tide condition. The measured parameters include light intensity, visibility, temperature, current velocity, salinity, $\mathrm{pH}$, dissolved oxygen, nitrate, phosphate and phytoplankton samples. Principal Component Analysis (PCA) was used to determine the characteristic of phytoplankton distribution. We found 14 genus of phytoplankton which consist of 13 genera of Bacillariophyceae and 1 genus of Dinophyceae. The entire observation stations were classified into four groups based on abundance and the genus of phytoplankton. The phytoplankton abundance ranged between 101 cell/l to 1071 cell/l. The phytoplankton abundance and distribution are in linear correlation with light intensity, visibility, $\mathrm{pH}$, dissolved oxygen, salinity and current velocity. This research could contribute on describing the water productivity level of Sugihan Estuary.

Keywords : distribution; PCA; phytoplankton; Sugihan Estuary

\begin{abstract}
Abstrak
Aktivitas di perairan Muara Sungai Sugihan berpotensi mengakibatkan perubahan kondisi fisika-kimia perairan yang berpengaruh pada kelimpahan dan distribusi fitoplankton. Tujuan penelitian ini untuk menganalisis kelimpahan dan distribusi fitoplankton dalam kaitannya dengan parameter fisika dan kimia perairan Muara Sugihan, Sumatera Selatan. Pengambilan sampel dilakukan pada 18 titik stasiun dalam kondisi perairan menuju surut. Parameter lingkungan yang diukur meliputi intensitas cahaya, kecerahan, suhu, kecepatan arus, salinitas, pH, oksigen terlarut, nitrat, fosfat dan sampel fitoplankton. Karakteristik sebaran fitoplankton dianalisis dengan menggunakan Analisis Komponen Utama (PCA). Hasil pengamatan fitoplankton ditemukan sebanyak 14 genus, 13 genus dari kelas Bacillariophyceae dan satu genus dari kelas Dinophyceae. Seluruh stasiun pengamatan dikelompokkan menjadi empat kelompok berdasarkan kelimpahan dan genus fitoplanktonnya. Kelimpahan fitoplankton berkisar antara $101 \mathrm{sel} / \mathrm{l}$ hingga $1071 \mathrm{sel} / \mathrm{l}$. Hubungan distribusi dan kelimpahan fitoplankton berbanding lurus dengan intensitas cahaya, kecerahan, $\mathrm{pH}$, oksigen terlarut, salinitas dan kecepatan arus. Penelitian ini dapat berkontribusi dalam menggambarkan tingkat kesuburan perairan di Muara Sungai Sugihan Sumatera Selatan.
\end{abstract}

Kata kunci : Analisis Komponen Utama; distribusi fitoplankton; Muara Sugihan 


\section{PENDAHULUAN}

Muara Sugihan merupakan salah satu muara sungai terbesar di Sumatera Selatan dan berlokasi diantara dua kabupaten yakni Kabupaten Banyuasin dan Kabupaten Ogan Komering llir, Sumatera Selatan. Ekosistem Muara Sugihan memiliki peranan sebagai habitat dari biota-biota besar hingga hingga organisme berukuran mikroskopik.

Fitoplankton merupakan organisme perairan berukuran mikroskopik yang memiliki kemampuan untuk menghasilkan energi sendiri dengan mengkonversi energi matahari dan zat hara menjadi energi kimia dalam bentuk karbohidrat (Suthers dan Rissik, 2009). Menurut Odum (1996), fitoplankton merupakan organisme yang menjadi produsen utama pada rantai makanan pada ekosistem perairan muara. Peranan fitoplankton menunjukan interaksi antara faktor biotik dan abiotik pada suatu ekosistem.

Muara sungai yang kaya zat hara berpengaruh terhadap pertumbuhan dan perkembangan fitoplankton. Hidup fitoplankton berlangsung dengan adanya zat hara sebagai sumber energinya (Muchlisin, 2001). Berbeda dengan perairan lepas pantai yang cenderung lebih miskin zat hara menyebabkan sebaran fitoplanktonnya cenderung rendah. Meskipun demikian, di beberapa tempat di laut juga ditemukan konsentrasi fitoplankton yang cukup tinggi. Keadaan tersebut disebabkan oleh adanya proses sirkulasi massa air yang memungkinkan terangkutnya sejumlah zat hara dari tempat lain (Odum, 1996).

Kondisi perairan muara Sungai Sugihan banyak dipengaruhi oleh aktivitas manusia yang semakin meningkat seperti kegiatan pertanian, industri dan limbah rumah tangga. Kondisi ini berpotensi mengakibatkan penurunan kualitas perairan yang akan mempengaruhi kelimpahan dan sebaran fitoplankton dalam kolom perairan.

Penurunan kualitas perairan dapat ditinjau dari parameter perairan. Parameterparameter perairan dibedakan menjadi parameter fisika, kimia dan biologi.
Parameter fisika diantaranya suhu, kecerahan, arus dan intensitas cahaya, parameter kimia antara lain salinitas, $\mathrm{pH}$, oksigen terlarut, nitrat dan fosfat, sedangkan untuk parameter biologi adalah fitoplankton. Informasi tentang kelimpahan dan distribusi fitoplankton berperan penting dalam menggambarkan tingkat kesuburan perairan di Muara Sungai Sugihan.

\section{MATERI DAN METODE}

Penelitian yang meliputi pengambilan sampel fitoplankton, air dan data parameter perairan dilakukan di Muara Sugihan. Stasiun penelitian terdiri atas 18 titik berdasarkan kriteria yang terdapat pada lokasi penelitian. Dari seluruh stasiun dibagi menjadi 3 zona yaitu sungai (Stasiun 1 - 5), muara (Stasiun 6 11), dan laut (Stasiun 12 - 28) yang dibedakan berdasarkan kadar salinitas (Gambar 1).

Pengukuran dan pengambilan sampel dilakukan pada saat cuaca cerah di kondisi perairan menuju surut. Pengambilan sampel air dari permukaan diambil dengan menggunakan ember kapasitas 10 liter sebanyak 50 liter, kemudian dituangkan ke dalam plankton net (mesh size $20 \square \mathrm{m}$ ). Sampel fitoplankton yang tersaring akan terkumpul pada penampungan plankton net, selanjutnya dituangkan ke dalam botol sampel dan dilakukan pengawetan dengan formalin hingga mencapai konsentrasi $4 \%$. Selanjutnya dilakukan pelabelan dan dimasukkan ke dalam coolbox. Bersamaan dengan pengambilan sampel air juga dilakukan pengukuran parameter lingkungan (suhu, salinitas, kecerahan, pH, oksigen terlarut, dan arus) secara in situ.

Peralatan yang digunakan pada penelitian ini meliputi plankton net (mesh size $20 \mu \mathrm{m}$ ), ember, formalin, botol sampel, DO meter, Current meter, kertas label, pH meter, Termometer, Hand refraktometer, Secchi disk, Iux meter, GPS, Cool box, alat tulis, es batu, pipet tetes, aquades, SRCC, mikroskop, buku identifikasi fitoplankton, perangkat komputer, dan spektrofotometer.

Identifikasi genus dan proses pencacahan fitoplankton berdasarkan 


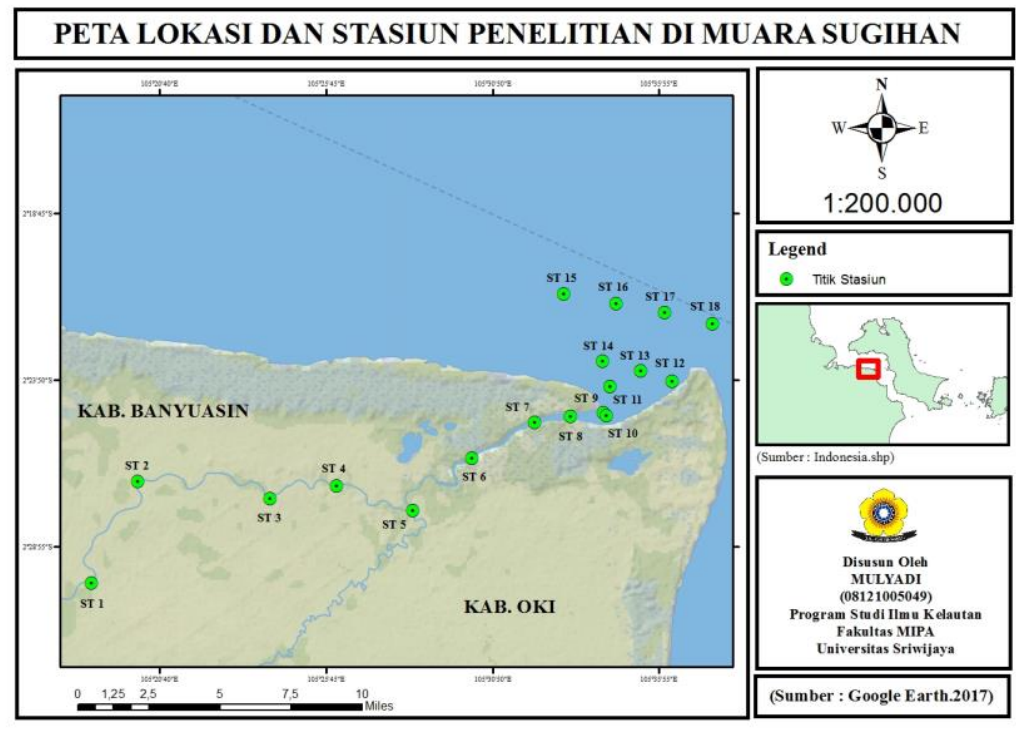

Gambar 1. Peta Lokasi Penelitian

Thomas (1997) dan Omura (2012) dilakukan dengan menggunakan mikroskop cahaya dengan perbesaan 10x. Analisis nitrat dan fosfat mengacu pada APHA (2005). Kelimpahan fitoplankton dihitung dalam sel/liter menggunakan persamaan Djumanto et al. (2009); Choirun et al. (2015)

Analisis pengelompokan dilakukan untuk melihat tingkat kesamaan kelimpahan dan keanekaragaman fitoplankton pada setiap stasiun melalui Cluster Analysis dengan bantuan perangkat lunak XLSTAT.

Distribusi Kelimpahan Fitoplankton dan Parameter Perairan dianalisis dengan menggunakan Analisis Komponen Utama (PCA) yang juga diolah dengan bantuan perangkat lunak XLSTAT.

\section{HASIL DAN PEMBAHASAN}

Terdapat 6 genus yang banyak ditemukan di perairan ini, yakni Chaetoceros, Ditylum, Leptocylindrus, Rhizosolenia, Thalassiosira dan Thalassionema (Gambar 2). Fitoplankton yang dijumpai pada seluruh stasiun pengamatan adalah Chaetoceros dan Odontella yang merupakan anggota dari kelas Bacillariophyceae. Genus Chaetoceros ditemukan $50 \%$ dari semua genus fitoplankton yang ditemukan. Genus Chaetoceros termasuk pada kelas
Bacillariophyceae dan merupakan genus yang paling banyak ditemukan dari semua genus pada seluruh stasiun. Menurut Praseno dan Sugestiningsih (2000), Chaetoceros merupakan salah satu genus dari tiga genus utama yang termasuk ke dalam kelas Bacillariophyceae.

Tingginya kelimpahan Chaetoceros diduga berkaitan dengan cara reproduksinya. Menurut Isnansetyo dan Kurniastuty (1995), Chaetoceros bereproduksi dengan cara pembelahan sel secara berulang ulang sehingga berdampak pada kelimpahan Chaetoceros yang meningkat dengan cepat. Chaetoceros juga merupakan genus fitoplankton yang hidup dengan membentuk rantai yang terdiri dari beberapa sel.

Kelimpahan fitoplankton antara 101 sel/l hingga 1071 sel/l dengan nilai rata-rata kelimpahan dari seluruh stasiun pengamatan sebanyak $431 \mathrm{sel} / \mathrm{l}$. Kelimpahan pada setiap stasiun memiliki nilai yang berbeda beda. Wulandari et al. (2014) menyatakan kandungan oksigen terlarut dan zat hara yang mencukupi adalah salah satu penyebab lebih tingginya kelimpahan fitoplankton pada suatu perairan.

Analisis pengelompokkan stasiun berdasarkan nilai kelimpahan fitoplankton disajikan 
pada Gambar 3. Pengelompokkan dilakukan secara cluster (Azhari, 2014).

Hasil analisis didapatkan 4 kelompok. Kelompok I terdiri dari stasiun 1 dan 18 yang berada di perairan sungai dan perairan laut, kelompok II terdiri dari stasiun 2 dan 8, stasiun ini berada pada perairan sungai dan perairan muara, kelompok III terdiri dari stasiun $3,4,5,6,7,9,10,11,12,13,15,16$ dan 17 yang mewakili dari seluruh zona perairan yaitu perairan sungai, muara, dan laut dan kelompok IV merupakan kelompok yang hanya beranggotakan stasiun 14 yang merupakan stasiun yang berada di perairan laut.
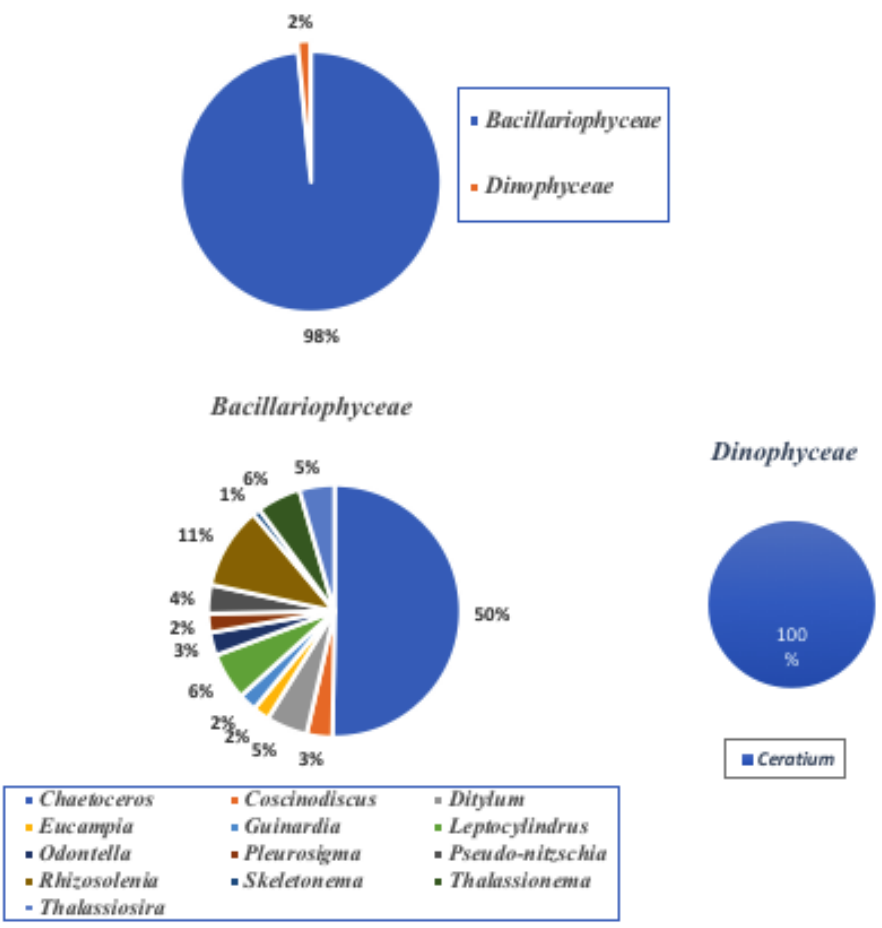

Gambar 2. Komposisi Fitoplankton

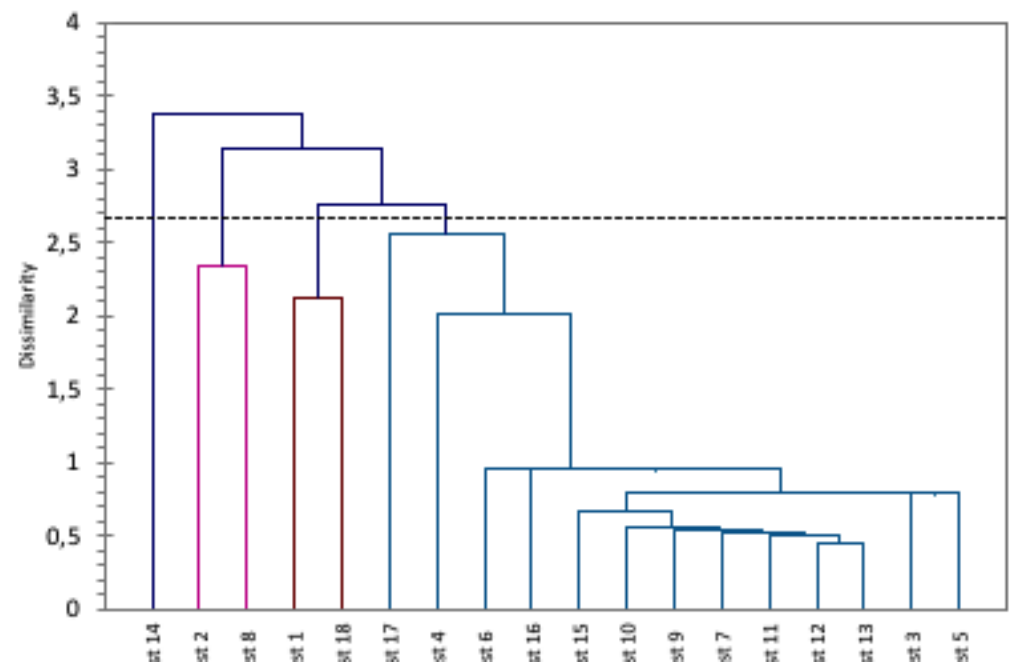

Gambar 3. Dendogram antar stasiun berdasarkan jumlah kelimpahan fitoplankton 
Stasiun-stasiun yang menjadi anggota kelompok I berada di perairan sungai dan perairan laut yang mengelompok menjadi satu kelompok yang keduanya memiliki keanekaragaman genus sedang tetapi kelimpahan dari setiap genusnya relatif sama-sama rendah dan memiliki kemiripan pada nilai dominansi dengan keriteria dominansi yang rendah. Kelompok II terdiri dari stasiun yang berada pada perairan sungai dan perairan muara, stasiun-stasiun ini memiliki jumlah genus yang cukup banyak tetapi kelimpahan dari setiap genusnya cenderung kecil, sehingga rata-rata kelimpahan fitoplankton pada stasiun-stasiun ini relative kecil tetapi secara keseluruhan stasiun ini termasuk stasiun yang memiliki keanekaragaman yang paling tinggi.

Stasiun-stasiun pada kelompok III pada umumnya memiliki kekhasan dimana stasiunstasiun ini cenderung memiliki kelimpahan genus Chaetoceros yang mendominasi genus-genus lainnya pada setiap stasiun yang termasuk dalam kelompok III, kelompok juga merupakan kelompok yang paling banyak memiliki anggota. Anggota dari kelompok mewakili dari seluruh zona perairan yaitu perairan sungai, muara, dan laut.

Kelompok IV merupakan kelompok yang hanya beranggotakan stasiun 14 yang merupakan stasiun yang berada di perairan laut. Hal ini diduga terjadi karena stasiun 14 memiliki kekhasan tersendiri, Kelimpahan
Rhizosolenia pada stasiun 14 merupakan yang paling banyak berkali-kali lipat dibandingkan dengan stasiun-stasiun lainnya yang cenderung sangat sedikit.

Adanya perbedaan ini menunjukkan bahwa komposisi fitoplankton sangat dipengaruhi faktor abiotik. Sesuai dengan pernyataan Widianingsih et al. (2007) bahwa faktor oseanografi pada suatu perairan, yang meliputi kedalaman pengambilan sampel, kecerahan, kecepatan arus, suhu, salintas, oksigen terlarut dan nutrien dapat mempengaruhi distribusi dan kelimpahan fitoplankton sehingga berbeda-beda. Dwirastina dan Makri (2014) menyatakan parameter yang mencerminkan kesuburan perairan adalah kecerahan, oksigen terlarut, $\mathrm{pH}$ dan kandungan zat hara. Analisis komponen utama sebaran genus Fitoplankton berdasarkan stasiun pengamatan disajikan pada Gambar 4.

Hasil analisis komponen utama didapatkan 14 sumbu untuk mencapai nilai komulatif 100\%, untuk mencapai nilai komulatif lebih besar dari $75 \%$ digunakan 4 sumbu yang terdiri dari F1 $(33,87 \%)$, F2 $(24,39 \%), F 3(10,56 \%)$ dan sumbu F4 $(9,092)$, kontribusi dari setiap sumbu memberikan arti bahwa hasil analisis komponen utama pada F1 dan F2 sebanyak 58,26\%, apabila ditambah dengan sumbu F3 maka menjadi $68,82 \%$ dan apabila ditambah F4 nilai komulatif mencapai 79,022\%.

Biplot (axes F1 and F2: $59.37 \%$ )

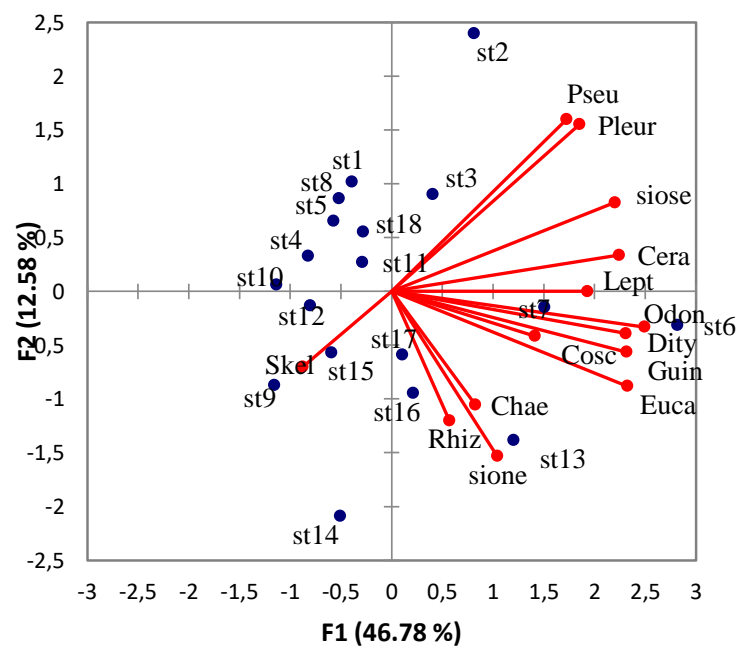

Gambar 4. Analisis komponen utama sebaran genus fitoplankton 
Hasil analisis komponen utama dari kelimpahan setiap genus fitoplankton pada 18 stasiun didapatkan 1 kelompok saja, pengelompokan terbentuk pada sumbu Fl dengan yang berkorelasi positif. Stasiunstasiun yang memiliki hubungan positif pada Fl adalah stasiun 6 dan 7 yang dicirikan oleh variabel Ditylum, Eucampia, Guinardia, Leptocylindrus, Odontella, Thalassiosira dan Ceratium. Stasiun yang memiliki korelasi negatif adalah stasiun 4, 5 dan 10 dengan tanpa variabel yang jadi pencirinya. Lebih lanjut analisis Komponen Utama keterkaitan parameter lingkungan (Tabel. 2) dengan Kelimpahan genus fitoplankton Berdasarkan Zona Perairan disajikan pada Gambar 5.

Hasil analisis komponen utama didapatkan dua sumbu dengan total nilai komulatif mencapai $100 \%$, dengan $\mathrm{Fl}$ yang memberikan kontribusi $66,91 \%$ dan F2 memberikan kontribusi sebanyak $33,09 \%$. Nilai $100 \%$ artinya hasil analisis ini dapat menjelaskan hubungan data keseluruhan.

Tabel 2. Kondisi parameter lingkungan di perairan Muara Sungai Sugihan

\begin{tabular}{ccccccccc}
\hline Stasiun & $\begin{array}{c}\text { Salinitas } \\
(\% \mathrm{O})\end{array}$ & $\begin{array}{c}\text { Suhu } \\
\left({ }^{\circ} \mathrm{C}\right)\end{array}$ & $\mathrm{pH}$ & $\begin{array}{c}\text { DO } \\
(\mathrm{mg} / \mathrm{l})\end{array}$ & $\begin{array}{c}\text { Kecerahan } \\
(\%)\end{array}$ & $\begin{array}{c}\text { Kec. Arus } \\
(\mathrm{m} / \mathrm{s})\end{array}$ & $\begin{array}{c}\text { Nitrat } \\
(\mathrm{mg} / \mathrm{l})\end{array}$ & $\begin{array}{c}\text { Fosfat } \\
(\mathrm{mg} / \mathrm{l})\end{array}$ \\
\hline 1 & 0,67 & 28,1 & 6,5 & 3,61 & 33,80 & 0,235 & 0,00063 & 0,0015 \\
2 & 0,61 & 28,9 & 6,6 & 3,22 & 38,10 & 0,154 & 0,00074 & 0,0009 \\
3 & 0,83 & 28,7 & 6,5 & 3,01 & 30,40 & 0,009 & 0,00075 & 0,0007 \\
4 & 1,09 & 28,4 & 6,6 & 3,10 & 32,30 & 0,038 & 0,00078 & 0,0009 \\
5 & 0,91 & 28,4 & 6,6 & 3,06 & 31,10 & 0,029 & 0,00057 & 0,0008 \\
6 & 3,23 & 28,0 & 6,9 & 3,56 & 50,70 & 0,457 & 0,00017 & 0,0006 \\
7 & 6,77 & 28,7 & 7,0 & 4,06 & 68,12 & 0,175 & 0,00009 & 0,0005 \\
8 & 10,48 & 28,1 & 7,8 & 4,96 & 65,44 & 0,125 & 0,00007 & 0,0006 \\
9 & 22,39 & 27,8 & 6,8 & 5,50 & 100,00 & 0,009 & 0,00016 & 0,0006 \\
10 & 17,91 & 27,6 & 7,6 & 6,03 & 60,41 & 0,009 & 0,00034 & 0,0006 \\
11 & 13,87 & 27,5 & 7,8 & 5,89 & 61,90 & 0,009 & 0,00007 & 0,0005 \\
12 & 33,69 & 26,6 & 7,1 & 5,29 & 95,11 & 0,009 & 0,00014 & 0,0005 \\
13 & 30,67 & 27,2 & 7,1 & 6,13 & 77,97 & 0,012 & 0,00012 & 0,0004 \\
14 & 32,76 & 27,4 & 7,2 & 6,10 & 71,03 & 0,646 & 0,00015 & 0,0005 \\
15 & 33,95 & 27,3 & 7,2 & 6,19 & 65,05 & 0,010 & 0,00010 & 0,0004 \\
16 & 34,69 & 27,4 & 7,2 & 6,16 & 63,75 & 0,009 & 0,00013 & 0,0006 \\
17 & 33,83 & 27,2 & 6,2 & 6,26 & 64,26 & 0,292 & 0,00010 & 0,0005 \\
18 & 34,32 & 27,6 & 6,7 & 6,12 & 63,58 & 0,292 & 0,00007 & 0,0016 \\
\hline
\end{tabular}

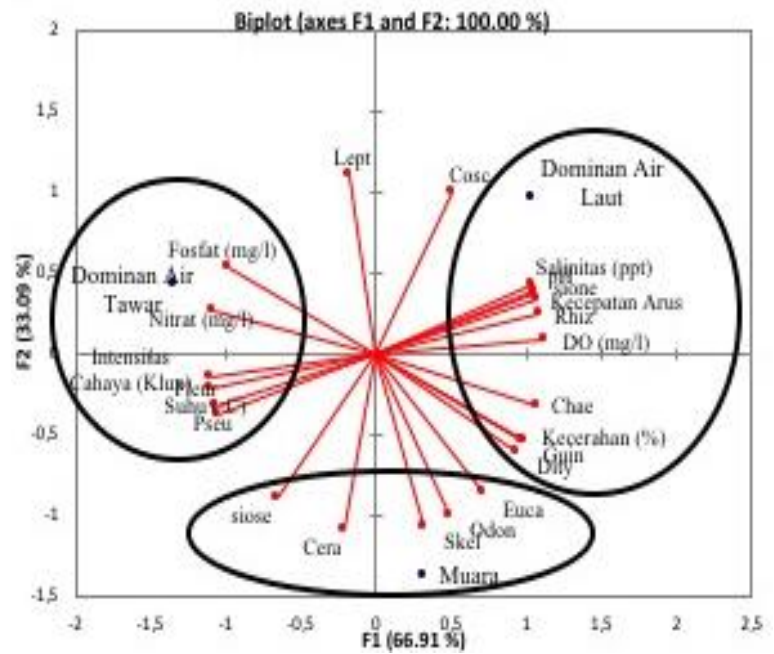

Gambar 5. Analisis komponen utama parameter lingkungan berdasarkan zona perairan Muara Sugihan 
Zona perairan muara sugihan yang dibagi atas sungai, muara dan laut, dari hasil analisis komponen utama terbentuk 3 kelompok yang tediri dari sumbu Fl negatif, F1 positif dan F2 negatif. Kelompok F1 negatif yaitu perairan sungai yang menunjukkan korelasi yang negatif dengan variabel penciri yaitu intensitas cahaya, nitrat, fosfat, Guinardia, Pleurosigma, Pseudo-nitzschia dan Thalassionema. Terdapatnya nitrat dan fosfat sebagai penciri pada perairan sungai mengindikasikan bahwa sumber masukan utama nitrat dan fosfat di perairan Muara Sugihan adalah dari daratan. Tinggi rendahnya kelimpahan fitoplankton dipengaruhi kandungan nitrat dan fosfat di perairan yang hubungannya berbanding lurus (Ayuningsih et al., 2014).

Kelompok $\mathrm{Fl}$ positif yaitu perairan laut dengan variabel pencirinya kecerahan, $\mathrm{pH}$, suhu, oksigen terlaut, salinitas, kecepatan arus, Chaetoceros dan Ditylum. Perairan laut ini menjadi perairan yang paling banyak dicirikan oleh parameter fisika dibandingkan dengan dua zona perairan lainnya. Kelompok F2 negatif yaitu perairan muara yang dicirikan oleh genus-genus fitoplankton yang memiliki kelimpahan rendah yaitu Eucampia, Odontella, Skeletonema, Thalassiosira dan Ceratium.

\section{KESIMPULAN}

Karakteristik sebaran berdasarkan zonasi perairan yakni perairan sungai terdiri dari intensitas cahaya, suhu, nitrat, fosfat, Pleurosigma dan Pseudo-nitzschia. Perairan muara dicirikan dengan Eucampia, Odontella, Skeletonema, Thalassiosira dan Ceratium. Karakteristik zona laut dicirikan oleh kecerahan, $\mathrm{pH}$, oksigen terlaut, salinitas, kecepatan arus, Chaetoceros, Ditylum, Rhizosolenia, Thalassionema dan Guinardia. Hubungan distribusi dan kelimpahan fitoplankton berbanding lurus dengan intensitas cahaya, kecerahan, $\mathrm{pH}$, oksigen terlarut, salinitas dan kecepatan arus.

\section{UCAPAN TERIMA KASIH}

Penulis mengucapkan terima kasih kepada RISTEKDIKTI dan Universitas Sriwijaya yang telah memberi dukungan finansial terhadap penelitian ini.

\section{DAFTAR PUSTAKA}

APHA. 2005. Standard Methods for the Examination of Water and Wastwater, 21st edition. American Public Health Association, Washington, D.C.

Azhari, M. 2014. Implementasi Analisis Cluster Berhierarki pada Bunga Mawar. Scan. 9(1):1-5

Ayuningsih, M.S., Boedi, H. \& Pujiono, W.P. 2014. Distribusi Kelimpahan Fitoplankton dan Klorofil-A Di Teluk Sekumbu Kabupaten Jepara : Hubungannya dengan Kandungan Nitrat dan Fosfat di Perairan. Diponegoro J. Maquares. 3(2):138-147

Choirun, A., Syarifah, H.J.S. \& Feni, I. 2015. Identifikasi Fitoplankton Spesies Harmfull Algae Bloom (HAB) Saat Kondisi Pasang di Perairan Brondong, Lamongan, Jawa Tengah. J. Ilmu Kelautan dan Perikanan. 25(2):58-66

Djumanto, Tumpak, S., Hanny, P. \& Reinhard, L. 2009. Pola Sebaran Horizontal dan Kerapatan Plankton di Perairan Bawean. J. Perikanan. 11 (1):115-122

Dwirastina M. \& Makri. 2014. Distribusi Spasial tehadap Kelimpahan, Biomassa Fitoplankton dan Keterkaitannya dengan Kesuburan Perairan di Sungai Rokan, Provinsi Riau. Limnotek. 21 (2):115-124

Isnansetyo A. \& Kurniastuty. 1995. Teknik kultur fitoplankton dan zooplankton. Kanisius: Yogyakarta.

Muchlisin, Z.A. 2001. Kelimpahan dan Keanekaragaman Plankton Sebagai Indikator Biologis Kerusakan dan Pencemaran Sungai Sarah di Kecamatan Lhoknga-Leupung Kabupaten Aceh Besar. J. Ilmiah. 3(2):7

Odum, E.P. 1996. Dasar-Dasar Ekologi edisi ke3. Alih Bahasa. Universitas Gajah Mada: Yogyakarta.

Omura, T., Mitsunori, I., Valeriano, M.B., Haruyoshi, T. \& Yasuwo, F. 2012. Marine Phytoplankton of the Western Pacific. Tokyo : Kouseishha Kouseikaku. 160 pp.

Praseno, D.P. \& Sugestiningsih. 2000. Retaid di Perairan Indonesia. Jakarta: P3O-LIPI.

Suthers, I.M. \& Rissik, D. 2009. Plankton A Guide to Their Ecology and Monitoring for Water Quality. CSIRO Publishing: Australia. 
Thomas, C.R. 1997. Identifying Marine Fitoplankton. California. USA : Academic Press.

Wulandari, D.Y., Niken, T.M.W.P. \& Enan, M.A. 2014. Distribusi Spasial Fitoplankton di
Perairan Pesisir Tangerang. J. IImu Pertanian Indonesia. 19(3):156-162 